\title{
ERRATUM TO: ANALYSIS OF FRUCTOSE AND MANNOSE - REGULATORY PEPTIDES SIGNALING PATHWAY IN PORCINE EPITHELIAL OVIDUCTAL CELLS (OECS) PRIMARY CULTURED LONG-TERM IN VITRO
}

\section{Erratum to:}

Analysis of fructose and mannose - regulatory peptides signaling pathway in porcine epithelial oviductal cells (OECs) primary cultured long-term in vitro

Mariusz J. Nawrocki, Joanna Budna, Piotr Celichowski, Ronza Khozmi, Artur Bryja, Wiesława Kranc, Sylwia Borys, Sylwia Ciesiółka, Sandra Knap, Michal Jeseta, Dorota Bukowska, Paweł Antosik, Klaus P. Brüssow, Małgorzata Bruska, Michał Nowicki, Maciej Zabel, Bartosz Kempisty Advances in Cell Biology 2017 Volume 5, Issue 2, pages 129-135 (DOI: 10.1515/acb-2017-0011)

The number of supporting grant was incorrect. For the reader's convenience, the corrected ACKNOWLEDGEMENTS chapter appears below:

ACKNOWLEDGEMENTS

Not applicable 